\title{
UNUSUAL RESPIRATORY MANIFESTATIONS OF ANKYLOSING SPONDYLITIS - A CASE REPORT
}

\author{
Ivan Cekerevac ${ }^{1,2}$, Vojislav Cupurdija ${ }^{1,2}$, Ljiljana Novkovic ${ }^{1,2}$, Zorica Lazic ${ }^{1,2}$, Marina Petrovic ${ }^{1,2}$, Olgica Gajovic ${ }^{1,2}$, Romana Susa ${ }^{1}$ \\ ${ }^{1}$ Clinical Centre Kragujevac, Clinic for Pulmonology, Kragujevac, Serbia \\ ${ }^{2}$ Faculty of Medical Sciences, University of Kragujevac, Kragujevac, Serbia
}

\author{
NEUOBIČAJENE RESPIRATORNE MANIFESTACIJE ANKILOZIRAJUĆEG \\ SPONDILITISA -PRIKAZ SLUČAJA \\ Ivan Čekerevac ${ }^{1,2}$, Vojislav Ćupurdija ${ }^{1,2}$, Ljiljana Novković1, ${ }^{1,2}$, Zorica Lazić ${ }^{1,2}$, Marina Petrović ${ }^{1,2}$, Olgica Gajović ${ }^{1,2}$, Romana Suša \\ ${ }^{1}$ Klinički centar Kragujevac, Klinika za pulmologiju, Kragujevac, Srbija \\ ${ }^{2}$ Fakultet medicinskih nauka, Univerzitet u Kragujevcu, Kragujevac, Srbija
}

\begin{abstract}
A male patient, 54 years old, was initially admitted to the hospital because of fatigue he felt during the last month and swelling of the lower legs. Upon hospital admittance, gas exchange analysis showed global respiratory failure: $\mathrm{pO}_{2}=6.1$ $\mathrm{kPa}, p \mathrm{CO}_{2}=10.9 \mathrm{kPa}, \mathrm{pH}=7.35$, A-a gradient $=1.0$. Due to the existence of hypercapnia and decompensated respiratory acidosis, the patient was connected to a device for non-invasive mechanical ventilation. Reduced chest mobility was noticed, and the respiratory index value was decreased. Radiographs of the chest and thoracic and lumbo-sacral spine showed marked changes on the spine attributable to ankylosing spondylitis (AS). Radiographs of the sacroiliac joints showed reduced sacroiliac joint intraarticular space with signs of subchondral sclerosis. The diagnosis of AS was set on the basis of New York Criteria (bilateral sacroiliitis, grade 3) and clinical criteria (back pain, lumbar spine limitation and chest expansion limitation). HLA typing (HLA B27+) confirmed the diagnosis of AS. Pulmonary function test proved severe restrictive syndrome. Polysomnography verified the existence of severe obstructive sleep apnoea $(A H I=73)$. This was a patient with newly diagnosed AS, with consequent severe restrictive syndrome and global respiratory failure with severe obstructive sleep apnoea. The patient was discharged from the hospital with a NIV (global respiratory failure) device for home use during the night.
\end{abstract}

Keywords: respiratory acidosis, ankylosing spondylitis, subchondral sclerosis.

\section{SAŽETAK}

Muškarac, star 54 godine, hospitalizovan zbog umora koji je osećao u poslednjih mesec dana i otoka nogu. Gasne analize na prijemu ukazuju na postojanje globalne respiratorne insuficijencije $\mathrm{pO}_{2}=6.1 \mathrm{Kpa}, p \mathrm{CO}_{2}=10.9 \mathrm{KPa}$. Z bog postojanja hiperkapnije $i$ dekompenzovane respiratorne acidoze, pacijent je priključen na aparat za neinvazivnu mehaničku ventilaciju. Zapažena je smanjena pokretliivost grudnog koša $i$ smanjena vrednost respiratornog indeksa. Na rendgengrafiji grudnog koša, torakalne i lumbo-sakralne kičme registrovane su promene koje bi mogle biti u sklopu ankilozirajućeg spondilitisa. Rendgenografijom sakroilijačnih zglobova registrovan je smanjen intraartikularni prostor sa znacima subhondralne skleroze. Dijagnoza ankilozirajućeg spondilitisa postavljena je na osnovu njujorških kriterijuma (bilateralni sakroileitis, treći stadijum) $i$ kliničkih kriterijuma (bol u leđima, ograničena pokretlivivost lumbalnog dela kičme i ograničena ekspanzija grudnog koša). HLA tipizacija (HLA B27 +) je potvrdila dijagnozu. Testovi plućne funkcije pokazali su težak restriktivni poreméaj. Polisomnografija je verifikovala postojanje teške opstruktivne sleep apnee (AHI=73). Ovo je bio pacijent sa novodijagnostikovanim AS što je za posledicu imalo težak restriktivni poremećaj sa značajno smanjenim respiratornim indeksom i razvoj hronične globalne respiratorne insuficijencije. Pacijent je otpušten iz bolnice i preveden na lečenje sa aparatom za neinvazivnu ventilaciju u kućnim uslovima.

Ključne reči: respiratorna acidoza, ankilozirajući spondilitis, subhondralna skleroza. 


\section{INTRODUCTION}

Ankylosing spondylitis (AS), or spondyloarthropathy, is a chronic, multisystem inflammatory disease that primarily affects the sacroiliac joints and the axial skeleton. AS can affect the tracheobronchial tree and pulmonary parenchyma, cause spontaneous pneumothorax and is associated with several unique pulmonary manifestations, such as upper lobe fibrocystic disease.

\section{CASE REPORT}

A male patient, 54 years old, was initially admitted to the hospital section of the Center for Emergency Medicine because of fatigue he felt during the last month and swelling of the lower legs. He denies any existence of chronic illness and does not take any medication. The result of gas exchange analysis upon admittance to the hospital showed global respiratory failure: $\mathrm{pO}_{2}=6.1 \mathrm{kPa}, \mathrm{pCO}_{2}=10.9 \mathrm{kPa}$, $\mathrm{pH}=7.35$, Aa gradient $=1.0$.

Chest radiography showed reduced transparency of lung parenchyma in the left basal area, as well as minor bilateral pleural effusion. ECG on admission registered sinus rhythm and incomplete right bundle branch block. Echocardiography examination was performed and showed excessive load and enlargement of the right atrium and ventricle of the heart (right ventricle $=40 \mathrm{~mm}$, average pressure in the right ventricle $=55 \mathrm{mmHg}$, tricuspidal regurgitation 4+). For further treatment and diagnosis, the patient was moved to the Clinic for Pulmonology. Subsequently, during detailed discussion with the patient, he reported in medical history that he had pain and limited mobility of the lumbar spine, significant daytime sleepiness, and loss of body weight ( $>10 \mathrm{~kg}$ during the last few months). General overview of the patient showed that he was conscious, with signs of central cyanosis and dyspnoea at rest, using auxiliary respiratory musculature and underweight $\left(B M I=18.4 \mathrm{~kg} / \mathrm{m}^{2}\right)$, with signs of systemic venous stasis. All haematology and biochemistry analysis, as well as thyroid hormones, showed results that were within normal ranges. Due to the existence of hypercapnia and decompensated respiratory acidosis, the patient was connected to a device for non-invasive mechanical ventilation (NIV). On the fifth day of hospitalization, despite the use of NIV (PSV $=24 \mathrm{cmH}_{2} \mathrm{O}$ ) and good patient compliance, respiratory acidosis was registered again, with worsening hypercapnia $\left(\mathrm{pH}=-7.29, \mathrm{PaCO}_{2}=14.9 \mathrm{kPa}\right)$. During further inspection, we noticed reduced chest mobility. The value of the respiratory index was decreased $-1.5 \mathrm{~cm}$. Due to the reduced respiratory index and worsening state of the patient's health, radiographic examinations of the chest and thoracic and lumbo-sacral spine were done, which showed antero and laterocorporal spondylophyte and ossification of the longitudinal anterior, posterior and lateral ligament (Figure 1).

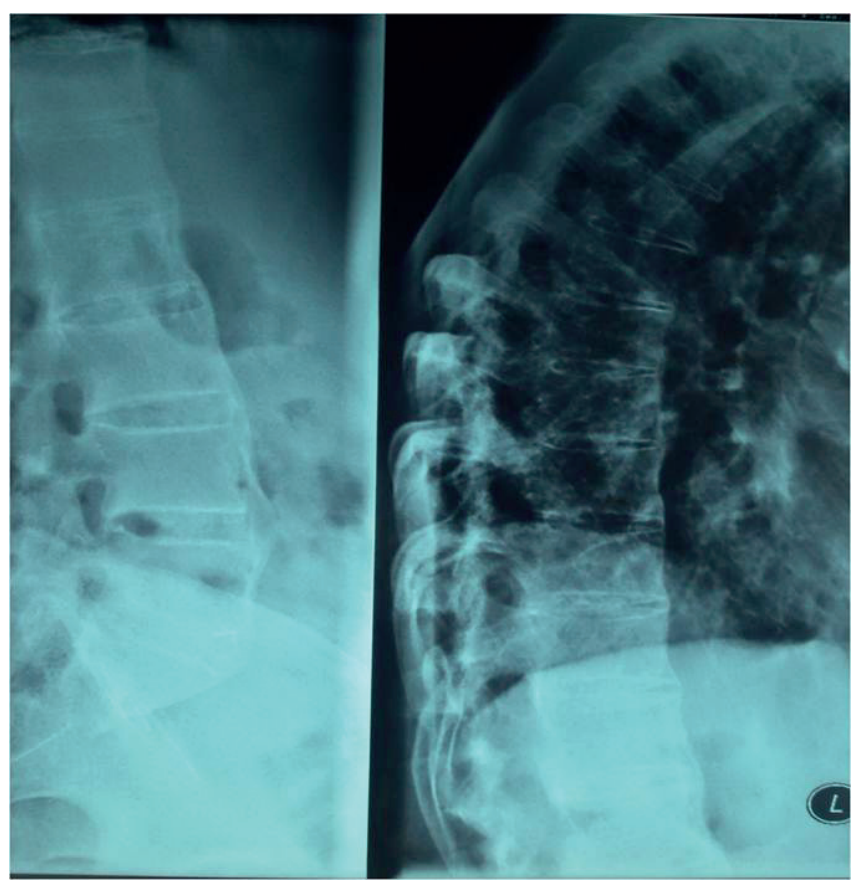

Figure 1. Radiograph of lumbosacral and thoracolumbal spine

A radiograph of the cervical spine was also taken and showed anterocorporal osteophytes and signs of anterior ligament calcification. Radiographs of the sacroiliac joints showed reduced bilateral sacroiliac joint intraarticular space with signs of subchondral sclerosis (Figure 2).

Chest HRCT was performed, which excluded changes in lung parenchyma and confirmed involvement of thoracic vertebrae. The diagnosis of AS was set on the basis of New York Criteria (bilateral sacroiliitis, grade 3) and clinical criteria (back pain, lumbal spine limitation and chest expansion limitation). HLA typing (HLA B27+) was subsequently performed and confirmed the diagnosis of ankylosing spondylitis.

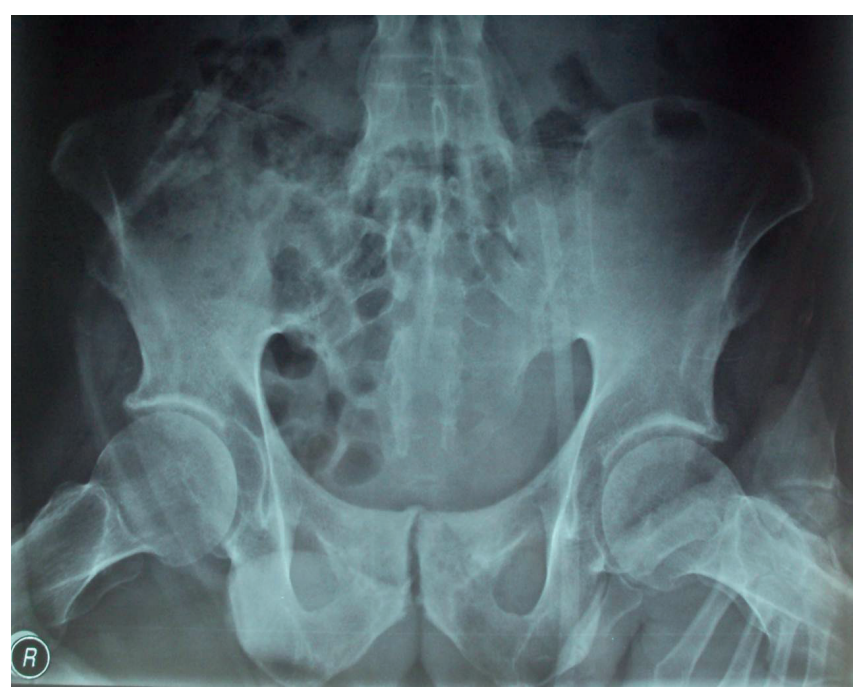

Figure 2. Radiograph of sacroiliac joints 
Figure 3 shows the consequences of AS on the costovertebral, costotransversal, sternoclavicular and sternomanubrial joints.

Pulmonary function test results indicated a severe restrictive disorder of the lungs $(\mathrm{FVC}=40 \%$, FEV1 $=$ $48 \%, \mathrm{FEV} 1 / \mathrm{FVC}=96.4$; body pletysmography: $\mathrm{TLC}=$ $65 \%)$. The testing of respiratory muscle force showed significant reduction in force, primarily of the inspirium muscles $($ Pimax $=20.2 \%$, Pemax $=45 \%)$. Due to excessive daytime sleepiness, a sleep study (polysomnography) was done that verified the existence of severe obstructive sleep apnoea $\left(\mathrm{AHI}=73\right.$, mean $\mathrm{SatO}_{2}=81 \%$, minimal $\mathrm{SatO}_{2}=51 \%$, while $\mathrm{SatO}_{2}<90 \%$ was registered over $76 \%$ of the recorded time).

After cardiorespiratory stabilisation, the patient was discharged from the hospital with a NIV (bilevel) device for home use during the night. Respiratory rehabilitation was recommended.

\section{DISCUSSION}

In the present case, AS was diagnosed in the late stage of the disease with the development of chronic respiratory failure based on observed changes on radiography of the vertebral column and positive HLA (human leukocyte antigen) typing. (1). This patient was diagnosed with AS at the age of 54, which places him in a group of $5 \%$ of the patients who became symptomatic after the age of 45 . The involvement of thoracic vertebrae, costovertebral, costotransverse, sternoclavicular and sternomanubrial joints results in an increase in dorsal kyphosis and rigidity of the thorax in patients with AS (2). Cerrahoglu et al. reported that sacroiliac joint and costovertebral joint involvement showed a statistically significant correlation with decreased chest expansion, longer disease duration and increased morning stiffness in AS (3).

The simplest way to estimate reduced respiratory movement of the thorax is by measuring respiratory index (RI) on the level of the 4th intercostal space (in our patient it was $1.5 \mathrm{~cm}$ ). A review of the literature shows that the mean value of RI in patients with AS is $3.9+-2.2 \mathrm{~cm}$, which is significantly lower than in the control group (5.6 $+-0.6 \mathrm{~cm}$ ) without AS (4). The same study found restrictive disorder in $33.3 \%$ of patients with AS. Additionally, there was a significant positive correlation between VC and FVC with the expansion of the thorax (RI) values (4). Results of the study from Vanderschueren (5) also showed that a restrictive lung function disorder is commonly associated with reduced expansion of the thorax. On the contrary, the study from Cerrahoglu (3) showed that the parameters of pulmonary function did not correlate significantly with the involvement of costotransversal and costovertebral joints and decreased expansion of the thorax.

Reduced respiratory muscle strength (especially inspirium muscles) was found in our patient, which further contributestoreducedmobilityofthechestandrestrictivesyndrome.
In clinical practice, respiratory muscle function is evaluated with maximum inspiratory pressure and maximum expiratory pressure. Chest wall mobility is often measured in clinical practice, but the correlations between chest wall mobility and respiratory muscle strength are unknown in patients with AS. In a study from de Cordoba et al., significant positive correlation was found between the strength of respiratory muscles (IPmax) and the mobility of the chest (thoracic cirtometry at the top of the processus xyphoideus) (6).

Our patient was also diagnosed with severe obstructive sleep apnoea (OSA). Literature review shows that the prevalence of OSA in patients with AS is from 12 to $22.6 \%$, which is significantly higher than the prevalence in the general population $(7,8)$. Significantly higher prevalence of OSA in AS was found in patients older than 35 years and with disease duration longer than 5 years (8). The assumed mechanisms that contribute to the occurrence of OSA in AS are reduced airway diameter at the level of the oropharynx due to the affection of the temporomandibular joint and compression of the trachea and pharynx due to the affection of the cervical spine.

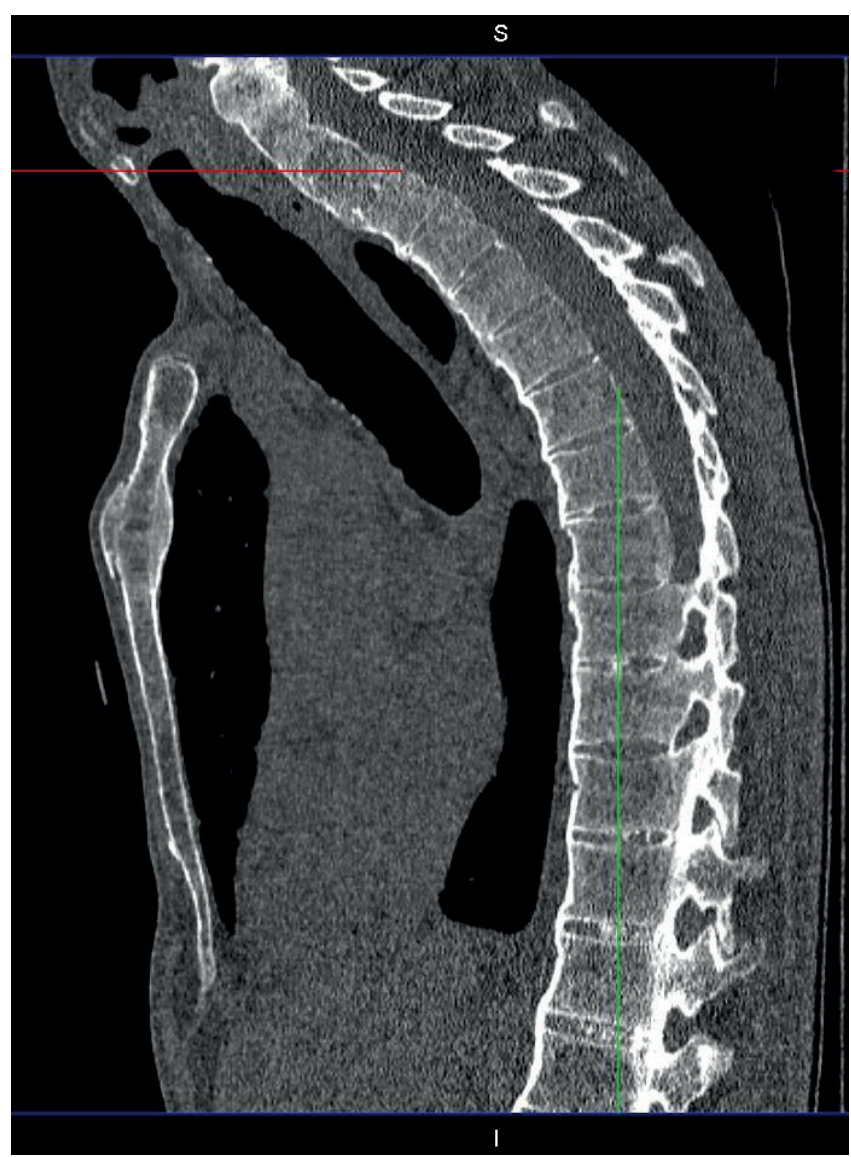

Figure 3. Spine and sternum CT scan 


\section{CONCLUSION}

It could be concluded that this is a patient with newly diagnosed ankylosing spondylitis at the age of 54, with consequent severe restrictive syndrome, secondary atrophy of respiratory muscles and global respiratory failure global respiratory failure with severe obstructive sleep apnoea.

\section{REFERENCES:}

1. Van den Berg R, Desiree M, van der Heijde. How should we diagnose spondyloarthritis according to the ASAS classification criteria. Pol Arch Med Wewn 2010; 120 (11): 452-458.

2. Hmamouchi I, Bahiri R, and Hajjaj-Hassouni N. Clinical and Radiological Presentations of Late-Onset Spondyloarthritis. ISRN Rheumatology 2011:3-7.

3. Cerrahoglu L, Unlu Z, Can M, Goktan C, Celik P. Lumbar stiffness but not thoracic radiographic changes relate to alternation of lung function tests in ankylosing spondylitis. Clin. Rheumatol 2002; 21:275-279.
4. Dincer U, Cakar E, Kiralp M, Bozkanat E, Kilac H, Dursun $\mathrm{H}$. The Pulmonary Involvement in Rheumatic Diseases: Pulmonary Effects of Ankylosing Spondylitis and Its Impact on Functionality and Quality of Life. Tohoku J Exp Med 2007; 212:423-430.

5. Vanderschueren D, Decramer M, Van den Daele P, Dequeker J. Pulmonary function and maximal transrespiratory pressures in ankylosing spondylitis. Ann Rheum Dis 1989;48: 632-635.

6. De Cordoba L, de Camargo A, Archija L, Rodrigues Selman J, Malaguti C and Dal Corso S. Chest wall mobility is related to respiratory muscle strenght and lung volumes in healhy subjects. Respiratory Care 2013; 58 (12):2107-2112.

7. İn E, Turgut T, Gulkesen A, Gundogdu G. Obstructive Sleep Apnea Syndrome and Sleep Efficiency in Patients with Ankylosing Spondylitis. Arch Rheumatol 2015;30: 35-39.

8. Solak O, Fidan F, Dundar U, Turel1 A, Aycicek A, Kavuncu1 Y, Unlu M. The prevalence of obstructive sleep apnea syndrome in ankylosing spondylitis patients. Rheumatology 2009; 48:433-435. 